\title{
The impact of four decades of annual nitrogen addition on dissolved organic matter in a boreal forest soil
}

\author{
M. O. Rappe-George, A. I. Gärdenäs, and D. B. Kleja \\ Department of Soil and Environment, Swedish University of Agricultural Sciences, P.O. Box 7014, 75007 Uppsala, Sweden
}

Correspondence to: M. O. Rappe-George (martin.rappe.george@ slu.se)

Received: 10 May 2012 - Published in Biogeosciences Discuss.: 13 September 2012

Revised: 9 January 2013 - Accepted: 15 January 2013 - Published: 1 March 2013

\begin{abstract}
Addition of mineral nitrogen $(\mathrm{N})$ can alter the concentration and quality of dissolved organic matter (DOM) in forest soils. The aim of this study was to assess the effect of long-term mineral $\mathrm{N}$ addition on soil solution concentration of dissolved organic carbon (DOC) and dissolved organic nitrogen (DON) in Stråsan experimental forest (Norway spruce) in central Sweden. $\mathrm{N}$ was added yearly at two levels of intensity and duration: the $\mathrm{N} 1$ treatment represented a lower intensity but a longer duration ( $43 \mathrm{yr}$ ) of $\mathrm{N}$ addition than the shorter $\mathrm{N} 2$ treatment ( $24 \mathrm{yr}$ ). $\mathrm{N}$ additions were terminated in the $\mathrm{N} 2$ treatment in 1991. The $\mathrm{N}$ treatments began in 1967 when the spruce stands were $9 \mathrm{yr}$ old. Soil solution in the forest floor $\mathrm{O}$, and soil mineral $\mathrm{B}$, horizons were sampled during the growing seasons of 1995 and 2009. Tension and non-tension lysimeters were installed in the $\mathrm{O}$ horizon $(n=6)$, and tension lysimeters were installed in the underlying B horizon $(n=4)$ : soil solution was sampled at two-week intervals. Although tree growth and $\mathrm{O}$ horizon carbon $(\mathrm{C})$ and $\mathrm{N}$ stock increased in treatments $\mathrm{N} 1$ and $\mathrm{N} 2$, the concentration of DOC in $\mathrm{O}$ horizon leachates was similar in both $\mathrm{N}$ treatments and control. This suggests an inhibitory direct effect of $\mathrm{N}$ addition on $\mathrm{O}$ horizon DOC. Elevated DON and nitrate in $\mathrm{O}$ horizon leachates in the ongoing $\mathrm{N} 1$ treatment indicated a move towards $\mathrm{N}$ saturation. In B horizon leachates, the N1 treatment approximately doubled leachate concentrations of DOC and DON. DON returned to control levels, but DOC remained elevated in B horizon leachates in N2 plots nineteen years after termination of $\mathrm{N}$ addition. We propose three possible explanations for the increased DOC in mineral soil: (i) the result of decomposition of a larger amount of root litter, either directly producing DOC or (ii) indirectly via priming of old SOM, and/or (iii) a suppression of extracellular oxidative enzymes.
\end{abstract}

\section{Introduction}

Soil carbon (C) in boreal forests is an important carbon pool globally (Schlesinger, 1977). Mineral soil generally contains more $\mathrm{C}$ than the forest floor O horizon (Callesen et al., 2003). Zech and Guggenberger (1996) estimated the proportion of dissolved organic carbon (DOC) in the total $\mathrm{C}$ input into the mineral soil in an acid forest soil in the Fichtelgebirge, Germany, to be as high as $75 \%$. In a more recent study of $\mathrm{C}$ fluxes in Swedish boreal forests this estimate was lower, ranging from $26 \%$ in the south to $10-15 \%$ in the north (Kleja et al., 2008). Moreover, structural similarities between dissolved organic matter (DOM) and solid-phase organic matter from the Spodosol mineral B horizon suggests that DOM is a significant source of $\mathrm{C}$ in spodic B horizons (Guggenberger et al., 1994). Once retained in the B horizon, adsorbed/precipitated DOM slowly mineralizes, probably due to its inherent recalcitrant nature and stabilization through the binding to $\mathrm{Al}$ and $\mathrm{Fe}$ (III) (Boudot et al., 1989; Kaiser and Guggenberger, 2000). Therefore, mobilization and transport of DOM in spodic soils are important processes in the $\mathrm{C}$ balance of boreal forests. Dissolved organic matter is an important component in the biogeochemical cycles of elements like nitrogen $(\mathrm{N})$ and phosphorous and can act as a vector for both naturally occurring and pollutant metals (Tyler, 1981).

In many areas in Europe the deposition of $\mathrm{N}$ is high and will probably remain so in the foreseeable future (Galloway et al., 2004). Measured $\mathrm{N}$ in throughfall indicates an unchanged or even slightly increased throughfall inorganic $\mathrm{N}$ concentration in the Swedish throughfall monitoring network nationwide during 1996-2008 (Pihl-Karlsson et al., 2011). Prolonged, high $\mathrm{N}$ inputs will decrease the decomposition rate of old soil organic matter (SOM) in temperate forest 
ecosystems (Berg and Matzner, 1997), and litter decomposition is negatively correlated to $\mathrm{N}$ enrichment, in particular for low quality substrates (Knorr et al., 2005). Also, there are reports of decreasing $\mathrm{C}$ mineralization rates from $\mathrm{O}$ horizon material following application of ammonium $\left(\mathrm{NH}_{4}^{+}\right)$ salts in laboratory studies (Sjöberg et al., 2003). Incomplete decomposition of lignin type SOM induced by high availability of $\mathrm{N}$ may be linked to an increase in availability of water soluble, partially decomposed lignin degradation products (Fog, 1988). Guggenberger (1994) found support for increasing dissolved organic carbon (DOC) fluxes and prevalence of products from incomplete lignin degradation in response to elevated deposition of $\mathrm{N}$ and sulphur (S) in German spruce forests. After one year of $\mathrm{N}$ amendment through applying sodium nitrate $\left(\mathrm{NaNO}_{3}\right)$ at $30 \mathrm{~kg} \mathrm{Nha}^{-1} \mathrm{yr}^{-1}$ to a North American deciduous forest stand, water-extractable DOC increased and the oxidative enzyme activity in soil was reduced (Sinsabaugh et al., 2004).

However, there is little information on how an elevated supply of $\mathrm{N}$ affects long-term leaching of DOM at stand level. In the Harvard Forest experiment in eastern North America, Currie et al. (1996) did not find a significant increase in the concentration of DOC in the forest floor after seven years of ammonium nitrate, $\mathrm{NH}_{4} \mathrm{NO}_{3}$, application. Conversely, in mature sugar maple dominated stands, the leaching of DOC through mineral soil increased (more than three times more than the control) and leaching of dissolved organic nitrogen $(\mathrm{DON})$ increased (more than six times more than the control) after the addition of $30 \mathrm{~kg} \mathrm{NO}_{3}-\mathrm{N} \mathrm{ha}^{-1} \mathrm{yr}^{-1}$ for eight years (Pregitzer et al., 2004). In the study by Pregitzer et al. (2004), the effect of elevated $\mathrm{N}$ deposition on leaching of DOC and DON in mineral B horizon was tested experimentally across a gradient of $\mathrm{N}$ availability, temperature and $\mathrm{N}$ deposition.

In $\mathrm{N}$ addition experiments, the contrasting effects of treatment on DOC might be explained by changes in soil acidity (Evans et al., 2008) because dissociation of functional groups can increase DOC solubility and presence of polyvalent cations limit it. In experiments where $\mathrm{N}$ addition probably acidified the soil (e.g. $\mathrm{N}$ added as $\mathrm{NH}_{4} \mathrm{SO}_{4}$ ), DOC in soil solution should decrease by this mechanism, whereas, if $\mathrm{N}$ addition decreased acidity (e.g. $\mathrm{N}$ added as $\mathrm{NaNO}_{3}$ ), DOC in soil solution should increase.

The leaching of DOC positively correlates with litterfall production in five coniferous forests across Europe (Gundersen et al., 1998). In a laboratory experiment the amount of substrate $\mathrm{C}$ increased the amount of extractable DOC (Park et al., 2002). However, the extent to which soil $\mathrm{C}$ and $\mathrm{N}$ stocks influence the concentration of DOC or DON is unclear (Kalbitz et al., 2000). As long-term $\mathrm{N}$ addition might influence net primary productivity (NPP) of the ecosystem, indirect effects of $\mathrm{N}$ addition, resulting from changes to soil $\mathrm{C}$ and $\mathrm{N}$ stocks, might affect soil solution DOC and DON concentration.
In the present study, a Norway spruce (Picea abies (L.) Karst) forest stand in central Sweden, E26A Stråsan (Tamm et al., 1974), was fertilized annually with ammonium nitrate, $\mathrm{NH}_{4} \mathrm{NO}_{3}$, beginning in 1967. The aim was to contrast the effect of long-term ( $>40 \mathrm{yr}$ ), intermediate-intensity $\mathrm{N}$ addition (37 $\mathrm{kg} \mathrm{Nha}^{-1} \mathrm{yr}^{-1}$ ) to shorter-duration (24 yr), highintensity $\mathrm{N}$ addition $\left(73 \mathrm{~kg} \mathrm{Nha}^{-1} \mathrm{yr}^{-1}\right)$ on soil solution concentration of DOC and DON in O and B horizon soil solution. The properties of the DOM, as determined by fractionation based on hydrophobicity and acidity (Leenheer, 1981), and UV absorbance at 254 and $280 \mathrm{~nm}$, were studied. The hypothesis was that $\mathrm{N}$ addition increased the formation of partially decomposed lignin degradation products found in $\mathrm{O}$ horizon, resulting in increased $\mathrm{DOC}$ concentrations in $\mathrm{O}$ and B horizon leachates. This increase in DOC should be linked with a higher abundance of aromatic moieties of the DOM, indicated by increased specific UV absorption (at 254 and $280 \mathrm{~nm}$ ) and an increased hydrophobicity of the DOM.

\section{Materials and methods}

\subsection{Site description}

The field site E26A Stråsan (Tamm et al., 1974) is an experimental spruce forest located $350 \mathrm{~m}$ above sea level in central Sweden $\left(60^{\circ} 55^{\prime} \mathrm{N}, 16^{\circ} 01^{\prime} \mathrm{E}\right)$. The soil type is classified as a haplic podzol (Berggren Kleja et al., 1998). Parent material consists of glacial till, with medium and fine sand as dominating fractions and a normal to high frequency of stones. Roots are present down into the mineral $\mathrm{B}$ horizon. Average horizon depths were $10 \mathrm{~cm}$ (O horizon), $6 \mathrm{~cm}$ (E horizon) and $14 \mathrm{~cm}$ (B1 horizon) in 2011.

The experiment was designed as a randomized block experiment with two blocks. Plots were $30 \mathrm{~m} \times 30 \mathrm{~m}$, with measuring plots of $25 \mathrm{~m} \times 25 \mathrm{~m}$. Measurements were taken in the control and $\mathrm{N}$-fertilized plots to which $\mathrm{NH}_{4} \mathrm{NO}_{3}$ had been added at average rates of $35(\mathrm{~N} 1)$ and $73(\mathrm{~N} 2) \mathrm{kg} \mathrm{ha}^{-1} \mathrm{yr}^{-1}$ (Table 1). The $\mathrm{N}$ addition in the $\mathrm{N} 1$ treatment was of lower intensity but longer duration ( $43 \mathrm{yr}$ ) than the $\mathrm{N} 2$ treatment, which was of higher intensity and shorter duration (24 yr). Although the $\mathrm{N}$ additions were terminated in the N2 treatment in 1990, the N2 plots had received a larger cumulative amount of $\mathrm{N}$ than the ongoing $\mathrm{N} 1$ treatment by 2009. The $\mathrm{NH}_{4} \mathrm{NO}_{3}$ salt was spread manually in May once a year. In 2009, manual application of ammonium nitrate was on 12 May, but for 1995 no application date was recorded.

Until the middle of the 1950s, the experimental area was covered with old Norway spruce-dominated (Picea abies (L.) Karst.) forest. Trees were felled in 1956 and the site was subjected to burning in the early summer of 1957 . Norway spruce seedlings were planted in the spring of 1958.

At a nearby meteorological station of the Swedish Hydrological and Meteorological Institute $\left(60^{\circ} 57^{\prime} \mathrm{N}, 16^{\circ} 26^{\prime} \mathrm{E}\right)$, the mean annual precipitation and temperature were 
Table 1. Nitrogen addition rates $\left(\mathrm{kg} \mathrm{N} \mathrm{ha}^{-1} \mathrm{yr}^{-1}\right)$ and total amount of $\mathrm{N}$ added 1967-2009 $\left(\mathrm{kg} \mathrm{N}\right.$ ha $\left.^{-1}\right)$ at Stråsan.

\begin{tabular}{lrrrr}
\hline Year & Duration & Control & N1 & N2 \\
\hline $1967-1969$ & $3 \mathrm{yr}$ & 0 & 60 & 120 \\
$1970-1976$ & $7 \mathrm{yr}$ & 0 & 40 & 80 \\
$1977-1990$ & $14 \mathrm{yr}$ & 0 & 40 & 60 \\
$1991-2009$ & $19 \mathrm{yr}$ & 0 & 30 & 0 \\
\hline Total 1967-2009 & $43 \mathrm{yr}$ & 0 & 1590 & 1760 \\
\hline
\end{tabular}

$584 \mathrm{~mm} \mathrm{yr}^{-1}$ and $4.3^{\circ} \mathrm{C}$ for the period 1995 to 2009 . The effective temperature sum (accumulated daily mean temperatures in excess of $5^{\circ} \mathrm{C}$ ) was $1163^{\circ} \mathrm{C}$ days in 1995 and $1209^{\circ} \mathrm{C}$ days in 2009 . The annual precipitation was $729 \mathrm{~mm}$ in 1995 and $733 \mathrm{~mm}$ in 2009 (data from SMHI, Swedish Hydrological and Meteorological Institute, http://www.smhi. se). Based on data for the period 1961 to 1990, snowmelt was usually complete by mid-April. The wet deposition of inorganic $\mathrm{N}$ at Stråsan was approximately $5.1 \mathrm{~kg} \mathrm{~N} \mathrm{ha}^{-1} \mathrm{yr}^{-1}$ in 1995/1996 and $3.2 \mathrm{~kg} \mathrm{~N} \mathrm{ha}^{-1} \mathrm{yr}^{-1}$ in 2009/2010 (data from IVL, Swedish Environmental Institute, http://www.ivl.se).

\subsection{Installation of lysimeters and sampling of soil solution}

Zero-tension lysimeters (ZTLs) were installed below the $\mathrm{O}$ horizon at 6 locations per plot to sample the water moving freely under the act of gravity. The ZTLs (BioKonsult, Skanör, Sweden) consisted of a Plexiglas trough $(30 \mathrm{~cm} \times 30 \mathrm{~cm})$ with two layers of polyethylene nets (mesh sizes $2 \mathrm{~mm}$ and $0.5 \mathrm{~mm}$ ) on top. The lysimeters were connected by silicone tubing to a borosilicate glass bottle. In addition, Rhizon-type lysimeters (R) were installed at the bottom of the $\mathrm{O}$ horizon, six in each plot, to sample the mesopore and micropore soil water through tension: the Rhizontype lysimeters were only sampled during 1995 .

In the lower B horizon $(\sim 50 \mathrm{~cm}$ depth), tension lysimeters (TLs) were installed at four locations in each plot. The TLs consisted of poly(tetraflourethylene) porous cup lysimeters (Prenart Equipment Aps, Frederiksberg, Denmark) with a pore size of $4 \mu \mathrm{m}$ : poly(tetraflourethylene) cups are chemically inert with respect to DOC (Beier and Hansen, 1992). Solutions were collected in borosilicate glass bottles. Both the TL cups and Rhizon lysimeters were operated at a transient vacuum with an initial tension of $-70 \mathrm{kPa}$.

All lysimeters were installed in the outer part of the projection of tree crowns to obtain a similar influence of throughfall on the lysimeter solutions. Collecting bottles were placed below ground in PVC tubes $(50 \mathrm{~cm})$ vertically installed in the soil. A lid consisting of styrofoam ensured that solutions were kept cool and dark during the sampling periods. The TLs were installed in June 1994 and the ZTLs in SeptemberOctober 1994.
The soil solution was sampled during two years: 20 June 1995 to 21 November 1995 and 8 June 2009 to 12 November 2009. For both years, the sampling interval was two weeks. The soil solution was sampled twelve times per year. Two sets of bottles were used for the solutions collected by ZTLs; these were used alternatively to enable bottles to be cleaned in the laboratory (rinsing with de-ionized water and burning at $200-250^{\circ} \mathrm{C}$ ) before each sampling period. The bottles for TLs were rinsed in the field with de-ionized water on each sampling occasion.

During 1995, samples from each lysimeter were analyzed separately, but for samples taken during 2009 so-called "pooled samples" were analyzed. Pooled samples were obtained by pouring the samples gathered by all lysimeters from the experimental plot into a large container from which a composite sample was taken and analyzed. Pooling of samples thus renders volume-weighted concentrations per plot. If a lysimeter had a larger volume than $1 \mathrm{dm}^{3}$, only a 1 $\mathrm{dm}^{3}$ sample from that specific lysimeter was added to the bulk sample. Samples from 1995 were calculated as volumeweighted concentrations by plot and sampling occasion.

\subsection{Chemical analyses of soil solution}

Samples were filtered through a $0.2-\mu \mathrm{m}$ filter and analyzed for $\mathrm{pH}$, total organic carbon (TOC), $\mathrm{NO}_{3}^{-}$(aq.), $\mathrm{NH}_{4}^{+}$(aq.), metals ( $\mathrm{Al}, \mathrm{Fe}, \mathrm{Mn}, \mathrm{Ca}, \mathrm{K}, \mathrm{Mg}, \mathrm{Na}$ ), anions $\left(\mathrm{Br}, \mathrm{Cl}, \mathrm{PO}_{4}\right.$, $\mathrm{SO}_{4}$ ) and total nitrogen (TN). The samples were stored at $+2{ }^{\circ} \mathrm{C}$ until analysis. DON was calculated by subtracting $\mathrm{N}$ content in inorganic $\mathrm{N}$ species $\left(\mathrm{NO}_{3}-\mathrm{N}\right.$ and $\left.\mathrm{NH}_{4}-\mathrm{N}\right)$ from the TN concentration. In 1995, DOC was fractionated into hydrophobic acids (HoA) and neutrals (HoN), and into hydrophilic acids (HiA), neutrals $(\mathrm{HiN})$ and bases $(\mathrm{HiB})$ with an adsorption chromatographic technique according to Leenheer (1981). In 2009, UV absorbance at 254 and $280 \mathrm{~nm}$ was measured. Specific UV absorbance, SUVA, was calculated by dividing UV absorbance $\left(\mathrm{m}^{-1}\right)$ by DOC concentration ( $\mathrm{mg} \mathrm{L}^{-1}$ ).

An aliquot for TOC analysis was filtered through $0.2-\mu \mathrm{m}$ filters (Acrodisc PF, Gelman Sciences, MI) and acidified to pH 3 with $\mathrm{HCl}$. In 1995, TOC measurements were made with a Shimadzu TOC-500 analyzer (Shimadzu Corporation, Kyoto, Japan); a Shimadzu TOC-VCPH analyzer was used in 2009. Analyses were usually performed within 1 week of sampling.

In 1995, TN samples were treated to persulphate oxidation $\left(10 \mathrm{~g} \mathrm{~K}_{2} \mathrm{~S}_{2} \mathrm{O}_{8}\right.$ in $1 \mathrm{~L}$ of $\left.0.15 \mathrm{M} \mathrm{NaOH}\right)$ by mixing equal volumes and boiling under pressure (14 kPa) for $25 \mathrm{~min}$. Before analysis of $\mathrm{NO}_{3}^{-}$by Flow Injected Analysis (FIA), $0.25 \mathrm{~mL}$ of $1.44 \mathrm{M} \mathrm{H}_{2} \mathrm{SO}_{4}$ was added. Determination of TN was performed with a Shimadzu TNM-1 TN analyzer (Shimadzu Corporation, Kyoto, Japan) in 2009.

Anions $\left(\mathrm{Br}, \mathrm{Cl}, \mathrm{PO}_{4}, \mathrm{SO}_{4}\right.$, and $\left.\mathrm{NO}^{-}\right)$were analyzed by ion chromatography using a Dionex 2000i/SP column in 1995 and a Metrosep A Supp 5 column in 2009. $\mathrm{NH}_{4}^{+}$was 
analyzed by a FIAStar 5000 analyzator (FOSS, Hilleroed, Denmark) in 2009. The limit of detection (LOD) for $\mathrm{NO}_{3}^{-}$ and $\mathrm{NH}_{4}^{+}$were $0.01 \mathrm{mg} \mathrm{L}^{-1}$. Values below detection limit were set to half LOD.

Metals (Al, Fe, Mn, Ca, K, Mg, and Na) were analyzed by a mass spectrometer, ELAN 6000, and an OPTIMA 3000 DV torch (Perkin Elmer, Waltham, USA). The pH of leachate solutions was measured with a microprocessor, ionalyzer/901 (Orion Research, Beverly, MA), using a combination glass electrode (Radiometer model PHC2002-8). UV absorbance was determined on a UV VIS spectrophotometer, Lambda 11 (Perkin Elmer, Waltham, USA), using a 10-mm cuvette.

As a measure of the potentially induced acidity of the experimental $\mathrm{N}$ additions, acid-neutralizing capacity (ANC) forcing (Evans et al., 2008) was calculated according to Eq. (1):

ANC forcing $=\Delta \mathrm{NH}_{4}^{+}-\Delta \mathrm{NO}_{3}^{-}$,

where $\Delta \mathrm{NH}_{4}^{+}$is the difference between treatment and control in mean annual soil solution concentration $\left(\mu\right.$ eq. $\left.\mathrm{L}^{-1}\right)$ of $\mathrm{NH}_{4}^{+}$, and $\Delta \mathrm{NO}_{3}^{-}$is the difference between treatment and control in mean annual soil solution concentration ( $\mu$ eq. $\mathrm{L}^{-1}$ ) of $\mathrm{NO}_{3}^{-}$.

\subsection{Sampling and analyses of soils}

Samples from the $\mathrm{O}_{i}$ and $\mathrm{O}_{e+a}$ horizon were taken in August 2010 with stainless steel cylinders (Ø $49 \mathrm{~mm}$ ). Six composite samples, each consisting of 25 subsamples, were taken from a grid in the measuring plots $(25 \mathrm{~m} \times 25 \mathrm{~m})$. Samples were weighed and then passed through a 4-mm sieve to remove coarse fragments and to homogenize the samples. Dry weights were determined after drying for at least $24 \mathrm{~h}$ at $105^{\circ} \mathrm{C}$. The $\mathrm{C}$ and $\mathrm{N}$ contents were determined from ground samples with a LECO elemental CNS-2000 analyzer (LECO Instruments, St. Joseph, USA).

For estimating the $\mathrm{C}$ and $\mathrm{N}$ stock in $\mathrm{O}_{e+a}$ horizon, the volume occupied by stones and boulders was corrected with the rod penetration method of Viro (1952). The percentage of stones and boulders in the $\mathrm{O}_{e+a}$ horizon was assumed equivalent to the percentage of penetrations that hit a stone on the surface or within the $\mathrm{O}_{e+a}$ horizon at a depth of less than half the mean depth of the $\mathrm{O}_{e+a}$ horizon. Data on $\mathrm{C}$ and $\mathrm{N}$ stock estimates made in 1996 were obtained from Andersson et al. (2002).

\subsection{Estimates of standing stem volume}

Trees were calipered in the experimental plots in both 1997 and 2010. The measurements were made in inner plots measuring $20 \mathrm{~m} \times 20 \mathrm{~m}$ and centered in the net plots which were $25 \mathrm{~m} \times 25 \mathrm{~m}$. The standing stock volume was estimated by the use of stand volume functions for Norway spruce, Picea abies (Brandel, 1990): standing dead trees were not included in the estimates. Total stemwood production was estimated by including data for thinned volumes, i.e. the volumes of trees cut down and removed for the benefit of the remaining stand. Data on diameter at breast height and height in 1997 were obtained from a database hosted by the Unit for Fieldbased Forest Research (Swedish University of Agricultural Sciences).

\subsection{Statistical analyses}

Treatment effects on the concentrations of DOC, DON, and properties of the DOM were analyzed as a randomized block experiment on time series soil solution data. Auto-correlation of any lag in time series data was not significant $(p>0.05)$. Moreover, the data indicated strong cross-correlation between time series of the different treatments. For analysis of soil solution data of DOC and DON during the years 1995 and 2009, a multiple linear model was fitted according to

$y_{i j k l}=\mu+\alpha_{i}+b_{j}+d_{i j}+t_{k}+m_{l}+e_{i j k l}$,

where

$$
\begin{aligned}
& -y_{i j k l}=\text { dependent variable } \\
& -\mu=\text { overall mean } \\
& -\alpha_{i}=\text { treatment effect } \\
& -b_{j}=\text { random block effect } \\
& -d_{i j}=\text { treatment } \times \text { year effect } \\
& -t_{k}=\text { effect of date of sampling } \\
& -m_{l}=\text { effect of year } \\
& -e_{i j k l}=\text { random error }
\end{aligned}
$$

Treatment, block, year, and date of sampling were treated as factors. The data were log-transformed prior to model evaluation in order to improve approximation to normality. Data on Leenheer fractionation (analyzed in 1995) and SUVA (analyzed in 2009) were treated in a similar model, but without year as a factor. The linear model was interpreted by analysis of variance (ANOVA). If significant treatment effects were indicated, post hoc analyses were continued with Tukey's honest significant difference (HSD) method.

The control plots repeatedly displayed soil solution $\mathrm{NO}_{3}^{-}$ and $\mathrm{NH}_{4}^{+}$below the detection limit; this was the reason these variables were not treated in the time series analysis. Instead, seasonal means were used. For data on non-time series $\left(\mathrm{NO}_{3}^{-}, \mathrm{NH}_{4}^{+}, \mathrm{pH}\right.$, ionic strength, soil $\mathrm{C}$ and $\mathrm{N}$, and standing tree volume), a linear model with treatment, block and year as factors was used. The linear model was interpreted by ANOVA. If significant treatment effects were indicated, post hoc analyses were made with the Tukey HSD method. 
Table 2. Soil carbon and nitrogen pools in 1996 and 2010 (tonnes $\mathrm{C}$ and $\mathrm{N} \mathrm{ha}^{-1}$, respectively). Values are mean \pm range ( $\left.n=2\right)$. Superscripts $\left({ }^{\mathrm{a}}, \mathrm{b},{ }^{\mathrm{c}}\right.$ and ${ }^{\mathrm{d}}$ ) denote significant differences at $P=0.05$ (Tukey HSD test). Within rows, means lacking a common superscript differ. Data from 1996 are from Andersson et al. (2001).

\begin{tabular}{|c|c|c|c|c|c|c|}
\hline & \multicolumn{3}{|c|}{1996} & \multicolumn{3}{|c|}{2010} \\
\hline & Control & N1 & $\mathrm{N} 2$ & Control & $\mathrm{N} 1$ & $\mathrm{~N} 2$ \\
\hline \multicolumn{7}{|c|}{ Carbon } \\
\hline $\mathrm{O}_{i}$ & $1.2 \pm 0.1^{\mathrm{a}}$ & $3.6 \pm 0.1^{b}$ & $4.0 \pm 0.4^{b}$ & $2.4 \pm 0.2^{\mathrm{c}}$ & $4.3 \pm 0.3^{b}$ & $3.7 \pm<0.1^{b}$ \\
\hline $\mathrm{O}_{e+a}$ & $18.2 \pm 3.2^{\mathrm{a}}$ & $39.0 \pm 8.8^{\mathrm{b}}$ & $44.7 \pm 4.1^{\mathrm{b}}$ & $20.2 \pm 2.6^{\mathrm{a}}$ & $45.1 \pm 10.0^{\mathrm{b}}$ & $45.5 \pm 3.2^{\mathrm{b}}$ \\
\hline Total & $19.4 \pm 3.3^{\mathrm{a}}$ & $42.6 \pm 8.9^{b}$ & $48.7 \pm 4.4^{b}$ & $22.6 \pm 2.7^{\mathrm{a}}$ & $49.4 \pm 10.2^{b}$ & $49.2 \pm 3.3^{b}$ \\
\hline \multicolumn{7}{|c|}{ Nitrogen } \\
\hline $\mathrm{O}_{i}$ & $0.03 \pm<0.01^{\mathrm{a}}$ & $0.13 \pm 0.01^{\mathrm{b}, \mathrm{c}}$ & $0.16 \pm 0.02^{b}$ & $0.06 \pm<0.01^{\mathrm{a}, \mathrm{d}}$ & $0.12 \pm<0.01^{\mathrm{b}, \mathrm{c}}$ & $0.10 \pm<0.01^{\mathrm{c}, \mathrm{d}}$ \\
\hline $\mathrm{O}_{e+a}$ & $0.54 \pm 0.09^{\mathrm{a}}$ & $1.44 \pm 0.30^{\mathrm{b}}$ & $1.77 \pm 0.17^{b}$ & $0.60 \pm 0.07^{\mathrm{a}}$ & $1.60 \pm 0.34^{\mathrm{b}}$ & $1.75 \pm 0.17^{b}$ \\
\hline Total & $0.57 \pm 0.09^{\mathrm{a}}$ & $1.57 \pm 0.31^{b}$ & $1.92 \pm 0.19^{b}$ & $0.66 \pm 0.07^{\mathrm{a}}$ & $1.73 \pm 0.34^{\mathrm{b}}$ & $1.85 \pm 0.17^{\mathrm{b}}$ \\
\hline
\end{tabular}

\section{Results}

\subsection{Soil $\mathbf{C}$ and $\mathbf{N}$}

The $\mathrm{C}$ and $\mathrm{N}$ stocks in the $\mathrm{O}_{i}$ and $\mathrm{O}_{e+a}$ horizons were larger in the $\mathrm{N}$-treated plots than control (Table 2). In 1996, the $\mathrm{C}$ stock in $\mathrm{O}_{i}+\mathrm{O}_{e+a}$ in treatment $\mathrm{N} 1 \quad\left(42.6 \pm 8.9\right.$ tonnes $\left.\mathrm{Cha}^{-1}\right)$ and $\mathrm{N} 2$ $\left(48.7 \pm 4.4\right.$ tonnes $\left.\mathrm{Cha}^{-1}\right)$ were more than double the C stock found in control $\left(19.4 \pm 3.3\right.$ tonnes $\left.\mathrm{ha}^{-1}\right)$. Although $\mathrm{N}$ addition was ended in treatment $\mathrm{N} 2$ by 1991 , the $\mathrm{C}$ stock was not significantly different from that in the ongoing $\mathrm{N}$ treatment, $\mathrm{N} 1$, in 2010. The largest increase in $\mathrm{C}$ stock (relative to control) was in the $\mathrm{O}_{i}$ horizon in 1996 and in the $\mathrm{O}_{e+a}$ horizon in 2010 for both $\mathrm{N}$ treatments. Soil carbon in $\mathrm{O}_{i+e+a}$ horizon increased by $19.4 \pm 4.6$ and $16.6 \pm 0.7 \mathrm{~kg} \mathrm{Cha}^{-1} \mathrm{yr}^{-1}$ per added $\mathrm{kg} \mathrm{Nha}^{-1} \mathrm{yr}^{-1}$ in treatments $\mathrm{N} 1$ and $\mathrm{N} 2$ in 1996: the corresponding figures were $16.8 \pm 4.7$ and $15.1 \pm 0.3 \mathrm{~kg} \mathrm{Cha}^{-1} \mathrm{yr}^{-1}$ per added $\mathrm{kg} \mathrm{Nha}^{-1} \mathrm{yr}^{-1}$ in 2010 .

The $\mathrm{N}$ stock in $\mathrm{O}_{i}+\mathrm{O}_{e+a}$ in 1996 was, similarly to $\mathrm{C}$ stock, more than double the control $\left(0.57 \pm 0.09\right.$ tonnes $\left.\mathrm{Nha}^{-1}\right) \quad$ in both $\mathrm{N}$ treatments $\left(1.57 \pm 0.31\right.$ and $1.92 \pm 0.19$ tonnes $\mathrm{Nha}^{-1}$ in $\mathrm{N} 1$ and $\mathrm{N} 2$ respectively). The $\mathrm{O}_{e+a}$ horizon $\mathrm{C}$ and $\mathrm{N}$ stocks presented the largest relative change in the ongoing $\mathrm{N} 1$ treatment during the period 1996 to 2010, although the difference between years was not significant $(p>0.05)$.

The $\mathrm{C} / \mathrm{N}$-ratio in the $\mathrm{O}_{e+a}$ horizon was $33 \mathrm{~g} \mathrm{~g}^{-1}$ for the control and $28 \mathrm{gg}^{-1}$ for N1 in both 1996 and 2010. The $\mathrm{C} / \mathrm{N}$-ratio in $\mathrm{O}_{e+a}$ horizon in the $\mathrm{N} 2$ treatment increased slightly, from $25 \mathrm{~g} \mathrm{~g}^{-1}$ in 1996 to $27 \mathrm{~g} \mathrm{~g}^{-1}$ in 2010. The $\mathrm{C} / \mathrm{N}$-ratio in the $\mathrm{O}_{e+a}$ horizon was lower than control in both $\mathrm{N}$ treatments. The $\mathrm{C} / \mathrm{N}$-ratio was higher in $\mathrm{O}_{i}$ than in $\mathrm{O}_{e+a}$ regardless of treatment. The lowest $\mathrm{C} / \mathrm{N}$-ratio in $\mathrm{O}_{i}$ horizon was found in the ongoing N1 treatment in 1996 (N1: $\left.28 \mathrm{gg}^{-1}\right)$.

\subsection{Tree stand development}

There were large increases in stemwood production in the fertilized plots by 1997 (Table 3). For treatments N1 and N2, stem volume increased by approximately $65 \%$, compared to control. The difference between the N1 and N2 plots was not significant $(p>0.05)$. In 2010, after an additional thirteen years of $\mathrm{N}$ addition in the $\mathrm{N} 1$ treatment, the increase in growth was less: $49 \%$ for N1 treatment (the corresponding figure for $\mathrm{N} 2$ was $55 \%$ ). This was partly explained by more thinned volumes in the $\mathrm{N} 1$ plots and that the standing tree volume in control plots increased from 163.5 to $286.2 \mathrm{~m}^{3}$ on bark ha ${ }^{-1}$ between 1997 and 2010.

By assuming a tree wood density of $500 \mathrm{~kg} \mathrm{~m}^{-3}$ and a C content of $50 \%$ (by mass), standing stemwood increased by $21.0 \pm 0.1$ and $15.7 \pm 0.4 \mathrm{~kg} \mathrm{Cha}^{-1} \mathrm{yr}^{-1}$ per kg N added $\mathrm{ha}^{-1} \mathrm{yr}^{-1}$ in treatments N1 and N2 in 1997: the corresponding figures were $21.4 \pm 0.8$ and $22.1 \pm 3.5 \mathrm{~kg} \mathrm{Cha}^{-1} \mathrm{yr}^{-1}$ per $\mathrm{kg} \mathrm{N}$ added $\mathrm{ha}^{-1} \mathrm{yr}^{-1}$ in 2010 .

\subsection{Soil solution chemistry}

\subsubsection{Dissolved organic carbon and nitrogen}

Soil solution DOC concentrations were highly variable in $\mathrm{O}$ horizon leachates throughout the growing season, ranging from 10 to $90 \mathrm{mg} \mathrm{L}^{-1}$ (Fig. 1); however, no clear seasonal pattern could be distinguished in either year in data from ZTLs or R-type lysimeters. The addition of $\mathrm{N}$ did not affect DOC in O horizon leachates in ZTLs or R-type lysimeters (Table 4). DOC annual mean concentration in both the $\mathrm{N} 1$ and N2 plots was slightly higher than in control plots in 2009 , but the effect was not significant. Regardless of treatment, DOC in ZTL leachates was higher in 2009 than in 1995 $(p<0.05)$.

In contrast, there were treatment effects in B horizon leachates for both years: during both 1995 and 2009, DOC in the low-intensity, ongoing N1 treatment was higher than 
Table 3. Standing tree volume, thinned and total production of stemwood $\left(\mathrm{m}^{3}\right.$ on bark ha $\left.{ }^{-1}\right)$ at Stråsan. Values are mean \pm range $(n=2)$. Superscripts $\left({ }^{\mathrm{a}},{ }^{\mathrm{b}},{ }^{\mathrm{c}}\right.$ and ${ }^{\mathrm{d}}$ ) denote significant differences at $P=0.05$ (Tukey HSD test). Within columns, means lacking a common superscript differ. Data on diameter at breast height and height in 1997 were obtained from the Unit for Field-based Forest Research database (Swedish University of Agricultural Sciences).

\begin{tabular}{|c|c|c|c|c|c|c|}
\hline & \multicolumn{3}{|c|}{1997} & \multicolumn{3}{|c|}{2010} \\
\hline & $\begin{array}{r}\text { Standing } \\
\text { tree } \\
\text { volume }\end{array}$ & $\begin{array}{l}\text { Thinned } \\
\text { volume }\end{array}$ & $\begin{array}{r}\text { Total } \\
\text { production }\end{array}$ & $\begin{array}{r}\text { Standing } \\
\text { tree } \\
\text { volume }\end{array}$ & $\begin{array}{l}\text { Thinned } \\
\text { volume }\end{array}$ & $\begin{array}{l}\text { Total } \\
\text { production }\end{array}$ \\
\hline Control & $163.5 \pm 2.5^{\mathrm{a}}$ & $7.6 \pm 0.5$ & $171.1 \pm 2.0^{\mathrm{a}}$ & $286.2 \pm 17.7^{\mathrm{c}}$ & $9.7 \pm 2.8$ & $295.9 \pm 14.9^{c}$ \\
\hline N1 & $267.0 \pm 2.0^{\mathrm{b}}$ & $46.2 \pm 2.3$ & $313.2 \pm 0.3^{b}$ & $424.7 \pm 12.7^{\mathrm{d}}$ & $16.0 \pm 8.2$ & $440.6 \pm 4.5^{\mathrm{d}}$ \\
\hline $\mathrm{N} 2$ & $274.5 \pm 0.5^{\mathrm{b}}$ & $39.7 \pm 13.3$ & $314.2 \pm 13.8^{b}$ & $442.1 \pm 7.0^{\mathrm{d}}$ & $1.1 \pm 1.1$ & $443.2 \pm 5.9^{\mathrm{d}}$ \\
\hline
\end{tabular}

in the control, and the DOC concentrations in the N2 treatment were higher than in $\mathrm{N} 1$. In comparison to $\mathrm{O}$ horizon leachates, mineral $\mathrm{B}$ horizon leachates were less variable. Moreover, DOC concentrations below the B horizon were generally an order of magnitude smaller than below the $\mathrm{O}$ horizon, indicating the large capacity for sorption/precipitation of DOM in the mineral soil. DOC in TL leachates was higher during 2009 than $1995(p<0.05)$ in all treatments. The annual means of DOC in both $\mathrm{O}$ horizon ZTL and B horizon TL leachates were correlated to the standing tree volume of individual plots (Fig. 2).

In 1995, DON concentrations in O horizon R-type lysimeter leachates were elevated in the N1 treatment, compared to both the control and N2. By 2009, O horizon ZTL leachate DON was higher in both $\mathrm{N} 1$ and $\mathrm{N} 2$ than in control plots $(p<0.05)$. Both N1 plots displayed elevated DON concentrations ( $>6 \mathrm{mg} \mathrm{DON} \mathrm{L}^{-1}$ ) during early summer 2009, and DON in mineral B horizon leachates were elevated approximately one month later (Fig. 1).

In B horizon leachates, DON in N1 plots were elevated in 2009 but not in 1995, similarly to ZTL leachates. By contrast, DON concentrations in N2 plots differed from control plots only in 1995. The difference in DON in B horizon leachates between 2009 and 1995 was not significant $(p>0.05)$.

DOC and DON concentrations in $\mathrm{O}$ horizon leachates were positively correlated with sampled water volume across sample collection dates ( $p<0.05$ for both) but with low explained variance (DOC $R^{2}=0.07$ and $\mathrm{DON} R^{2}=0.01$ ). In $\mathrm{B}$ horizon lysimeters, DOC concentrations were positively correlated with sampled water volume $(p<0.05$; $\left.R^{2}=0.36\right)$, but DON concentrations were not $(p=0.29)$. ZTL and R-type lysimeter leachates did not correlate with respect to either DOC ( $p=0.19)$ or DON $(p=0.11)$ on time series data, indicating that the two lysimeter types sampled different kind of soil waters.

As O horizon leachate DOC concentration was unchanged but DON concentration increased in the N1 treatment, the DOC/DON-ratio decreased. In 1995 the DOC/DON-ratio on annual mean concentrations in $\mathrm{O}$ horizon leachates was $70 \%$ of control in both $\mathrm{N}$ treatments (Fig. 3). In 2009, the
DOC / DON-ratio in the N1 treatment was $41 \%$ of control: the corresponding figure for the $\mathrm{N} 2$ treatment was $78 \%$. The annual mean DOC/DON in ZTL leachates did not show a $1: 1$ relationship with $\mathrm{C} / \mathrm{N}$ in the $\mathrm{O}$ horizon (Fig. 2). Especially N1 plots DOC / DON were low in 2009, because DON was elevated. The response of SOM and DOM to long-term $\mathrm{N}$ addition thus differed, at least in time lag.

\subsubsection{Hydrophobicity, acid-base and UV absorbance of leachate DOM}

No effect of treatment on the hydrophobicity or acidity of DOM was observed in O horizon leachates, estimated by Leenheer fractionation (Table 5). Hydrophobic and hydrophilic acids were the dominating fractions of the DOM (>90\% by mass) in leachates from both R-type lysimeters and ZTLs. Thus, neutrals and bases constituted low proportions of the DOM $(<10 \%)$.

$\mathrm{SUVA}_{254 \mathrm{~nm}}$ and $\mathrm{SUVA}_{280 \mathrm{~nm}}$ did not reveal any treatment effects in O horizon leachates in 2009 (Table 6), confirming the results from Leenheer fractionation. However, in the mineral B horizon, $\mathrm{SUVA}_{254} \mathrm{~nm}$ was higher $(p<0.05)$ in $\mathrm{N} 1$ and $\mathrm{N} 2$ plots compared to control. SUVA $280 \mathrm{~nm}$ was only elevated in the $\mathrm{N} 2$ plots $(p<0.05)$.

\subsubsection{Ionic strength and acidity}

Ionic strength in the $\mathrm{O}$ horizon soil solution recovered in ZTL leachates was higher in N1 than in the control in both 1995 and 2009 (Table 7): N2 plots did not display higher ionic strength than control plots in ZTL leachates. In mineral B horizon, the ionic strength of sampled soil solution was not higher than the control in both the $\mathrm{N} 1$ and $\mathrm{N} 2$ plots $(p>$ 0.05).

The concentration of $\mathrm{NO}_{3}^{-}$and $\mathrm{NH}_{4}^{+}$recovered in ZTL leachates was higher in the $\mathrm{N} 1$ plots than control and $\mathrm{N} 2$ in 1995 and 2009 (Table 7). This resulted in ANC forcing in the range $-250-50 \mu \mathrm{eq} \mathrm{L}^{-1}$ in $\mathrm{O}$ horizon and $-54-3 \mu \mathrm{eq} \mathrm{L}^{-1}$ in $\mathrm{B}$ horizon leachates for N1 and N2. However, ANC forcing showed no linear correlation with relative change of DOC $(\%)$ in $\mathrm{N}$-treated plots in $\mathrm{O}$ or B horizon leachates $(p=0.24$ 
Table 4. Means (95\% confidence intervals) of concentrations of dissolved organic carbon (DOC) and dissolved organic nitrogen (DON) in $\mathrm{O}$ and B horizon leachates in 1995 and 2009 at Stråsan $(n=24)$. Both DOC and DON are in mg L ${ }^{-1}$. Superscripts $\left({ }^{\mathrm{a}}\right.$, b ${ }^{\mathrm{c}}$ and $\left.{ }^{\mathrm{d}}\right)$ denote significant differences at $P=0.05$ (Tukey HSD). Within lysimeter type and variable, means lacking a common superscript differ. Significant interaction Treatment * Year found for DON in ZTLs and TLs.

\begin{tabular}{|c|c|c|c|c|}
\hline Horizon & & Control & $\mathrm{N} 1$ & $\mathrm{~N} 2$ \\
\hline \multirow[t]{7}{*}{$\mathrm{O}$} & \multicolumn{4}{|c|}{ Zero tension lysimeters } \\
\hline & \multicolumn{4}{|l|}{ DOC } \\
\hline & 1995 & $28.7(19.1-43.2)^{\mathrm{a}}$ & $29.2(19.4-44.1)^{\mathrm{a}}$ & $27.4(18.2-41.3)^{\mathrm{a}}$ \\
\hline & 2009 & $41.3(33.5-50.9)^{\mathrm{b}}$ & $55.5(45.1-68.3)^{\mathrm{b}}$ & $53.0(43.0-65.4)^{\mathrm{b}}$ \\
\hline & \multicolumn{4}{|l|}{ DON } \\
\hline & 1995 & $0.9(0.6-1.2)^{\mathrm{a}}$ & $1.1(0.8-1.6)^{\mathrm{a}, \mathrm{b}}$ & $0.9(0.6-1.3)^{\mathrm{a}}$ \\
\hline & 2009 & $1.0(0.7-1.4)^{\mathrm{a}}$ & $3.4(2.4-4.9)^{\mathrm{c}}$ & $1.9(1.3-2.7)^{\mathrm{b}}$ \\
\hline \multirow[t]{5}{*}{$\mathrm{O}$} & \multicolumn{4}{|c|}{ Rhizon lysimeters } \\
\hline & \multicolumn{4}{|l|}{ DOC } \\
\hline & 1995 & $51.3(44.2-59.5)^{\mathrm{a}}$ & $46.5(40.1-53.9)^{\mathrm{a}}$ & $51.6(44.5-59.8)^{\mathrm{a}}$ \\
\hline & \multicolumn{4}{|l|}{ DON } \\
\hline & 1995 & $1.1(0.8-1.4)^{\mathrm{a}}$ & $3.1(2.3-4.2)^{\mathrm{b}}$ & $1.3(1.0-1.7)^{\mathrm{a}}$ \\
\hline \multirow[t]{7}{*}{ B } & \multicolumn{4}{|c|}{ Tension lysimeters } \\
\hline & \multicolumn{4}{|l|}{ DOC } \\
\hline & 1995 & $1.5(1.2-2.0)^{\mathrm{a}}$ & $2.1(1.6-2.7)^{\mathrm{b}}$ & $3.4(2.7-4.5)^{\mathrm{C}}$ \\
\hline & 2009 & $2.3(1.7-3.1)^{\mathrm{b}}$ & $3.3(2.5-4.5)^{\mathrm{c}}$ & $4.7(3.5-6.3)^{\mathrm{d}}$ \\
\hline & \multicolumn{4}{|l|}{ DON } \\
\hline & 1995 & $0.07(0.05-0.09)^{\mathrm{a}}$ & $0.11(0.09-0.14)^{\mathrm{a}, \mathrm{b}, \mathrm{c}}$ & $0.14(0.11-0.18)^{\mathrm{b}, \mathrm{c}}$ \\
\hline & 2009 & $0.08(0.06-0.12)^{\mathrm{a}, \mathrm{d}}$ & $0.19(0.13-0.27)^{\mathrm{b}}$ & $0.11(0.08-0.15)^{\mathrm{c}, \mathrm{d}}$ \\
\hline
\end{tabular}
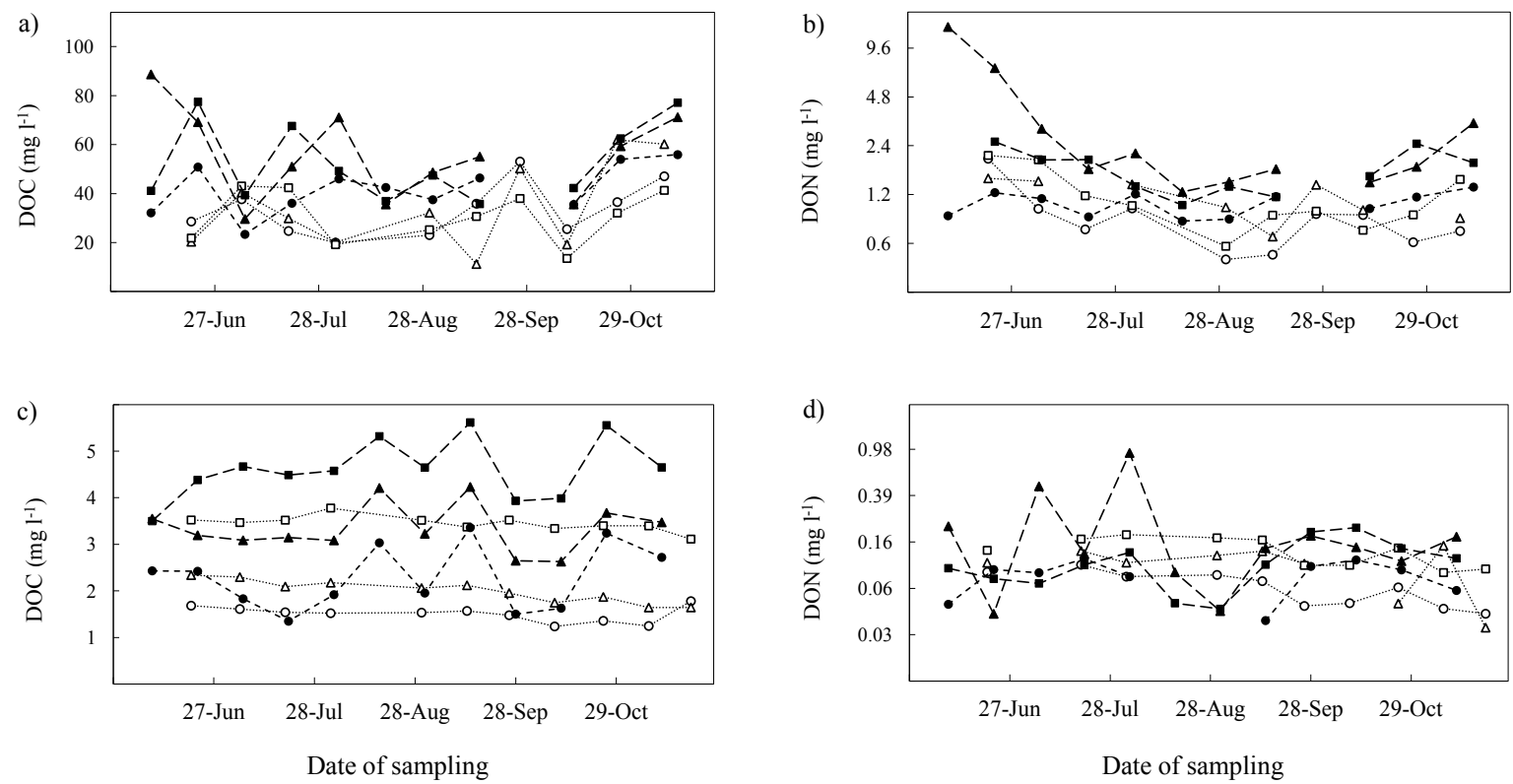

\begin{tabular}{|c|c|c|c|c|c|}
\hline o. Control 1995 & -.NN1 1995 & ㅁ.N2 1995 & - Control 2009 & $\rightarrow-N 12009$ & $\rightarrow-N 22009$ \\
\hline
\end{tabular}

Fig. 1. Concentrations of dissolved organic carbon, DOC, (a and c) and dissolved organic nitrogen, DON, (b and d) in O horizon ZTL (a and b) and mineral B horizon TL (c and d) leachates during the growing season of 1995 and 2009. Both DOC and DON are in mg L ${ }^{-1}$. Note that the scales on the $y$-axis are logarithmic in both (b) and (d). 
Table 5. Leenheer fractionation of O horizon leachates at Stråsan experimental forest measured in 1995. Data from Zero tension lysimeters $($ ZTL) and rhizon lysimeters $(\mathrm{R})$ are shown. Values are mean $\pm 95 \%$ confidence intervals $(n=4)$. No effect of treatment was found at $P=0.05$.

\begin{tabular}{|c|c|c|c|c|c|c|}
\hline \multirow[b]{2}{*}{ Lysimeter } & \multirow[b]{2}{*}{ Treatment } & \multicolumn{2}{|c|}{ Hydrophobic } & \multicolumn{3}{|c|}{ Hydrophilic } \\
\hline & & Acids & Neutrals & Acids & Neutrals & Bases \\
\hline ZTL & Control & $48.4 \pm 8.8$ & $5.9 \pm 2.2$ & $37.0 \pm 4.4$ & $4.4 \pm 2.6$ & $4.3 \pm 1.9$ \\
\hline ZTL & N1 & $48.9 \pm 8.7$ & $8.1 \pm 2.2$ & $34.9 \pm 4.4$ & $3.9 \pm 2.7$ & $4.3 \pm 2.0$ \\
\hline ZTL & $\mathrm{N} 2$ & $45.6 \pm 9.3$ & $9.5 \pm 2.5$ & $39.6 \pm 4.9$ & $1.7 \pm 2.8$ & $4.4 \pm 2.1$ \\
\hline $\mathrm{R}$ & Control & $58.2 \pm 5.2$ & $2.5 \pm 2.7$ & $36.2 \pm 5.5$ & $2.1 \pm 1.2$ & $1.1 \pm 1.0$ \\
\hline $\mathrm{R}$ & N1 & $60.2 \pm 6.0$ & $2.6 \pm 2.9$ & $33.0 \pm 6.2$ & $2.8 \pm 1.4$ & $1.4 \pm 1.1$ \\
\hline $\mathrm{R}$ & $\mathrm{N} 2$ & $55.9 \pm 5.2$ & $2.9 \pm 2.8$ & $36.6 \pm 5.4$ & $2.8 \pm 1.2$ & $1.9 \pm 1.3$ \\
\hline
\end{tabular}

a)

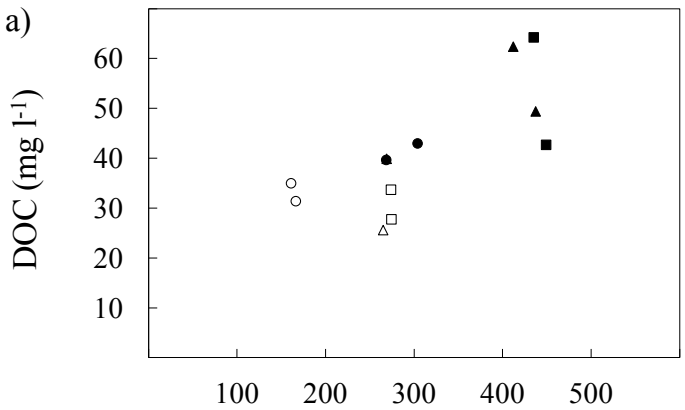

Standing tree volume $\left(\mathrm{m}^{-3} \mathrm{ha}^{-1}\right)$ b)

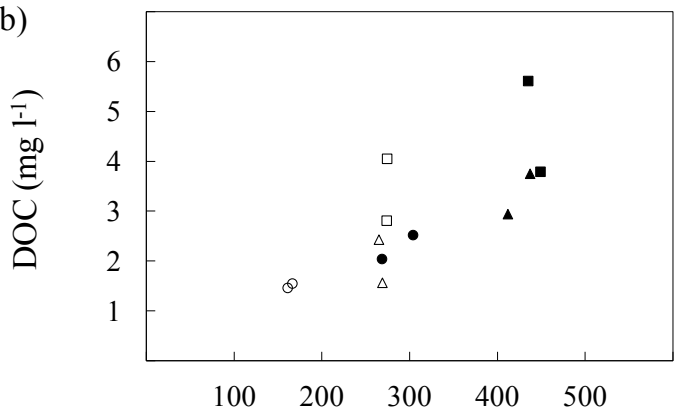

Standing tree volume $\left(\mathrm{m}^{-3} \mathrm{ha}^{-1}\right)$

$$
\circ \text { Control } 1995\lrcorner \text { N1 } 1995 \square \text { N2 } 1995 \bullet \text { Control } 2009 \quad \Delta \text { N1 } 2009 \quad \text { N2 } 2009
$$

Fig. 2. Annual means of dissolved organic carbon, DOC, concentration $\left(\mathrm{mg} \mathrm{L}^{-1}\right)$ in O horizon ZTLs (a) and mineral B horizon TLs (b), and standing tree volume $\left(\mathrm{m}^{3} \mathrm{ha}^{-1}\right)$ at Stråsan. Standing tree volume was determined in 1997 and 2010.

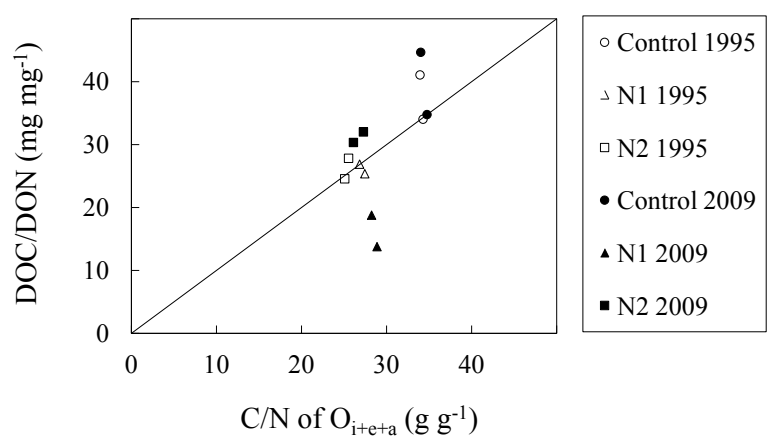

Fig. 3. Dissolved organic carbon/dissolved organic nitrogen, DOC / DON, $\left(\mathrm{mg} \mathrm{mg}^{-1}\right)$ of annual means per plot in O horizon ZTL leachates and carbon/nitrogen, $\mathrm{C} / \mathrm{N},\left(\mathrm{g} \mathrm{g}^{-1}\right)$ of $\mathrm{O}_{i+e+a}$ at Stråsan. $\mathrm{O}_{i+e+a}$ horizon carbon and nitrogen were determined in 1996 and 2010. Drawn line is the $1: 1$ line.

and $p=0.35$ respectively). Significant treatment effects on $\mathrm{pH}$ were only present in R-type lysimeter leachates (lower $\mathrm{pH}$ in N1 plots). Accordingly, there was no support for acidity as a driver of DOC at Stråsan (Fig. 4).

\section{Discussion}

Contrary to our initial hypothesis, the concentration and the quality of DOC sampled in $\mathrm{O}$ horizon leachates did not change in response to long-term addition of mineral $\mathrm{N}$ at Stråsan experimental forest. This finding was in accordance with some lysimeter studies (Currie et al., 1996; Raastad and Mulder, 1999) but stood in contrast to others (Guggenberger, 1994; Pregitzer et al., 2004). The variability in response of DOC to $\mathrm{N}$ addition has not been uniformly explained. Acid/base effect of $\mathrm{N}$ fertilizer (Evans et al., 2008) and ecosystem-specific response of the microbial community (Waldrop and Zak, 2006) have been proposed to explain between-site differences of DOC response to $\mathrm{N}$ addition.

Fröberg et al. (2006) identified a positive correlation between $\mathrm{O}$ horizon leachate mean annual DOC concentration and aboveground biomass across a gradient of climate and primary productivity in Sweden. We observed a similar relationship in our study (Fig. 3), although we are aware of temporal pseudo-replication. The standing tree volume is a major determinant of litterfall production in Norway spruce forest stands (Saarsalmi et al., 2007), and litter is a significant 
Table 6. Specific UV absorbance at $254\left(\mathrm{SUVA}_{254} \mathrm{~nm}\right)$ and $280 \mathrm{~nm}$ $\left(\mathrm{SUVA}^{280 \mathrm{~nm}}\right)$ at Stråsan experimental forest in $\mathrm{O}$ horizon and B horizon leachates. Both SUVA $254 \mathrm{~nm}$ and SUVA280nm are in $\mathrm{L} \mathrm{mg}^{-1} \mathrm{~m}^{-1}$. Values are mean $\pm 95 \%$ confidence intervals $(n=$ 24). Superscripts ( ${ }^{\mathrm{a}},{ }^{\mathrm{b}}$ and ${ }^{\mathrm{c}}$ ) denote significant differences at $P=$ 0.05 (Tukey HSD test). Within column and soil horizon, means lacking a common superscript differ.

\begin{tabular}{llrr}
\hline Horizon & Treatment & SUVA $_{254 \mathrm{~nm}}$ & $\mathrm{SUVA}_{280 \mathrm{~nm}}$ \\
\hline $\mathrm{O}$ & Control & $4.2 \pm 0.2^{\mathrm{a}}$ & $3.1 \pm 0.2^{\mathrm{a}}$ \\
$\mathrm{O}$ & $\mathrm{N} 1$ & $4.1 \pm 0.3^{\mathrm{a}}$ & $3.1 \pm 0.2^{\mathrm{a}}$ \\
$\mathrm{O}$ & $\mathrm{N} 2$ & $4.0 \pm 0.3^{\mathrm{a}}$ & $3.0 \pm 0.2^{\mathrm{a}}$ \\
\hline $\mathrm{B}$ & Control & $1.1 \pm 0.2^{\mathrm{a}}$ & $0.8 \pm 0.2^{\mathrm{a}}$ \\
$\mathrm{B}$ & $\mathrm{N} 1$ & $1.3 \pm 0.2^{\mathrm{b}}$ & $0.9 \pm 0.2^{\mathrm{a}}$ \\
$\mathrm{B}$ & $\mathrm{N} 2$ & $1.9 \pm 0.3^{\mathrm{c}}$ & $1.3 \pm 0.2^{\mathrm{b}}$ \\
\hline
\end{tabular}

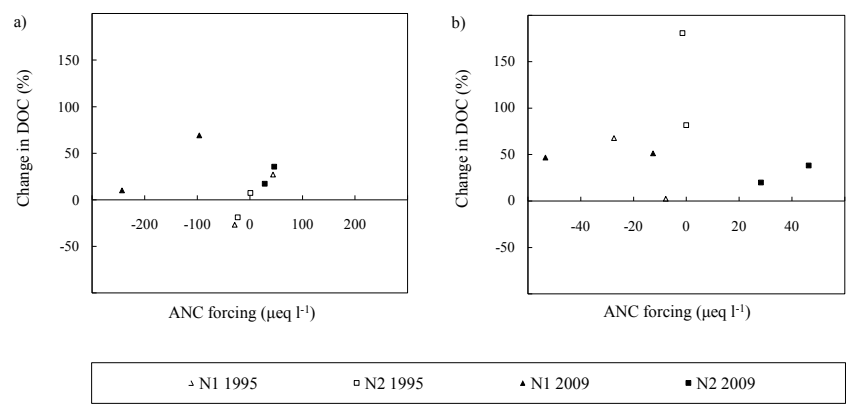

Fig. 4. Change in dissolved organic carbon, DOC, by treatments N1 and N2 (change in \% of annual mean of Control) in O horizon ZTLs (a) and mineral B horizon TLs (b) and acid neutralizing capacity (ANC) forcing in mueq $\mathrm{L}^{-1}$ (Evans et al., 2008) at Stråsan.

source of DOC in O horizon soil solution (Fröberg et al., 2005). An indirect positive effect of $\mathrm{N}$ addition on DOC in $\mathrm{O}$ horizon, through the production and subsequent decomposition of aboveground litter, thus seemed likely. The fact that year was a significant factor in our ANOVA $(P<0.05)$ complemented this observation (Table 4), as well as the fact that amount of precipitation and the effective temperature sums at a nearby weather station were similar in 1995 and 2009 (see Sect. 2.1 Site description). As we did not observe treatment effects on DOC in O horizon leachates, the direct effect of $\mathrm{N}$ addition on $\mathrm{DOC}$ in $\mathrm{O}$ horizon at Stråsan was inhibitory per unit substrate $\mathrm{C}$ (soil $\mathrm{C}$ and litterfall production). This was corroborated by the fact that standing tree volumes and $\mathrm{O}_{i}$ and $\mathrm{O}_{e+a}$ horizon $\mathrm{C}$ stocks increased in $\mathrm{N} 1$ and $\mathrm{N} 2$, but $\mathrm{O}$ horizon DOC was similar in control and $\mathrm{N}$-amended plots in both 1995 and 2009. The same effect was found for ZTLs and R-type lysimeters although they sampled different soil water. Data on soil water content at 0.2 and $0.5 \mathrm{~m}$ depth in the control and N1 plots (sampled during April-July 2012) did not indicate changes to the soil moisture sufficient to cause a concentration effect (M. O. Rappe-George, unpublished data, 2012). Moreover, there is support that water flux through the
Table 7. Nitrate $\left(\mathrm{NO}_{3}\right)$, ammonium $\left(\mathrm{NH}_{4}\right)$ both in $\mathrm{mg} \mathrm{NL}^{-1}, \mathrm{pH}$ and ionic strength $\left(\mathrm{mmol} \mathrm{L}^{-1}\right)$ at Stråsan in 1995 and 2009. Values are mean \pm range $(n=2)$. Superscripts $\left({ }^{\mathrm{a}},{ }^{\mathrm{b}},{ }^{\mathrm{c}}\right.$ and $\left.{ }^{\mathrm{d}}\right)$ denote significant differences at $P=0.05$ (Tukey HSD test). Within lysimeter type and variable, means lacking a common superscript differ.

\begin{tabular}{|c|c|c|c|}
\hline & Control & N1 & $\mathrm{N} 2$ \\
\hline \multicolumn{4}{|c|}{ Zero tension lysimeters } \\
\hline \multicolumn{4}{|l|}{$\mathrm{NO}_{3}-\mathrm{N}$} \\
\hline 1995 & $0.02 \pm<0.01^{\mathrm{a}}$ & $1.6 \pm 0.51^{\mathrm{b}}$ & $0.35 \pm 0.10^{\mathrm{a}}$ \\
\hline 2009 & $0.03 \pm 0.02^{\mathrm{a}}$ & $3.7 \pm 0.65^{\mathrm{b}}$ & $0.11 \pm 0.09^{\mathrm{a}}$ \\
\hline \multicolumn{4}{|l|}{$\mathrm{NH}_{4}-\mathrm{N}$} \\
\hline 1995 & $0.25 \pm<0.02^{\mathrm{a}}$ & $1.8 \pm 0.83^{\mathrm{b}}$ & $0.50 \pm 0.01^{\mathrm{a}}$ \\
\hline 2009 & $0.30 \pm 0.11^{\mathrm{a}}$ & $1.8 \pm 0.17^{b}$ & $0.87 \pm 0.31^{\mathrm{a}}$ \\
\hline \multicolumn{4}{|l|}{$\mathrm{pH}$} \\
\hline 1995 & $4.39 \pm 0.11^{\mathrm{a}}$ & $4.34 \pm 0.06^{\mathrm{a}}$ & $4.31 \pm 0.12^{\mathrm{a}}$ \\
\hline 2009 & $4.12 \pm 0.02^{b}$ & $3.98 \pm 0.06^{\mathrm{b}}$ & $3.97 \pm 0.01^{\mathrm{b}}$ \\
\hline \multirow{2}{*}{\multicolumn{4}{|c|}{$\begin{array}{l}\text { Ionic } \\
\text { strength }\end{array}$}} \\
\hline & & & \\
\hline 1995 & $0.06 \pm<0.01^{\mathrm{a}}$ & $0.14 \pm 0.04^{\mathrm{b}}$ & $0.09 \pm<0.01^{\mathrm{a}, \mathrm{b}}$ \\
\hline 2009 & $0.16 \pm<0.01^{\mathrm{c}}$ & $0.38 \pm 0.05^{\mathrm{d}}$ & $0.24 \pm 0.09^{\mathrm{c}, \mathrm{d}}$ \\
\hline \multicolumn{4}{|c|}{ Rhizon lysimeters } \\
\hline \multicolumn{4}{|l|}{$\mathrm{NO}_{3}-\mathrm{N}$} \\
\hline 1995 & $<0.01 \pm<0.01^{\mathrm{a}}$ & $4.3 \pm 2.0^{\mathrm{a}}$ & $0.11 \pm<0.01^{\mathrm{a}}$ \\
\hline \multicolumn{4}{|l|}{$\mathrm{NH}_{4}-\mathrm{N}$} \\
\hline 1995 & $0.06 \pm<0.01^{\mathrm{a}}$ & $1.6 \pm 1.3^{\mathrm{a}}$ & $0.21 \pm 0.03^{\mathrm{a}}$ \\
\hline \multicolumn{4}{|l|}{$\mathrm{pH}$} \\
\hline 1995 & $4.07 \pm 0.03^{\mathrm{a}}$ & $3.83 \pm 0.03^{\mathrm{b}}$ & $3.93 \pm 0.01^{\mathrm{a}}$ \\
\hline \multicolumn{4}{|l|}{$\begin{array}{l}\text { Ionic } \\
\text { strenoth }\end{array}$} \\
\hline $\begin{array}{c}\text { strength } \\
1995\end{array}$ & $0.07 \pm 0.02^{\mathrm{a}}$ & $0.22 \pm 0.08^{\mathrm{a}}$ & $0.08 \pm 0.02^{\mathrm{a}}$ \\
\hline \multicolumn{4}{|c|}{ Tension lysimeters } \\
\hline \multicolumn{4}{|l|}{$\mathrm{NO}_{3}-\mathrm{N}$} \\
\hline 1995 & $<0.01 \pm<0.01^{\mathrm{a}}$ & $0.20 \pm 0.07^{\mathrm{a}}$ & $<0.01 \pm<0.01^{\mathrm{a}}$ \\
\hline 2009 & $0.01 \pm<0.01^{\mathrm{a}}$ & $0.47 \pm 0.28^{\mathrm{a}}$ & $0.01 \pm<0.01^{\mathrm{a}}$ \\
\hline \multicolumn{4}{|l|}{$\mathrm{NH}_{4}-\mathrm{N}$} \\
\hline 1995 & $0.01 \pm<0.01^{\mathrm{a}}$ & $0.01 \pm<0.01^{\mathrm{a}}$ & $0.01 \pm<0.01^{\mathrm{a}}$ \\
\hline 2009 & $0.01 \pm<0.01^{\mathrm{a}}$ & $<0.01 \pm<0.01^{\mathrm{a}}$ & $<0.01 \pm<0.01^{\mathrm{a}}$ \\
\hline \multicolumn{4}{|l|}{$\mathrm{pH}$} \\
\hline 2009 & $5.35 \pm 0.05^{\mathrm{a}}$ & $5.36 \pm 0.14^{\mathrm{a}}$ & $4.94 \pm 0.01^{\mathrm{a}}$ \\
\hline \multicolumn{4}{|l|}{$\begin{array}{l}\text { Ionic } \\
\text { strength }\end{array}$} \\
\hline 2009 & $0.16 \pm 0.05^{\mathrm{a}}$ & $0.23 \pm 0.03^{\mathrm{a}}$ & $0.23 \pm<0.01^{\mathrm{a}}$ \\
\hline
\end{tabular}

soil does not greatly affect DOC concentration, even at high rates (Fröberg et al., 2006; Kalbitz et al., 2007; Schmidt et al., 2010).

In accordance with our hypothesis regarding DOC concentration in mineral B horizon, DOC approximately doubled in both sampling years in response to both $\mathrm{N}$ treatments, $\mathrm{N} 1$ and $\mathrm{N} 2$. These findings were in accordance with other reports on the effects of $\mathrm{N}$ addition on mineral horizon DOC across a range of ecosystem types (Guggenberger, 1994; Pregitzer et al., 2004). As there were no treatment effects in O horizon leachates, the increased DOC in mineral soil requires an explanation other than increased leaching of DOC from the overlying $\mathrm{O}$ horizon. We found no support that changes 
to acidity or ionic strength explained the increase in DOC concentration in the N-treated plots (Table 7). A decrease in either ANC forcing or ionic strength would have been needed. Ionic strength increased slightly in $\mathrm{N} 1$ and N2 plots, but the effect was not significant $(p=0.27)$. The seasonal means of DOC appeared to correlate with the standing tree volume also in B horizon leachates (Fig. 3). A larger standing tree biomass was likely to have increased root biomass (Cairns et al., 1997) and thus litter input to mineral soil via root litter and/or rhizodeposition. The treatment effects on DOC in mineral soil could take on three possible explanations, alone or in combination. First, it is possible that elevated DOC with a higher SUVA at 254 and $280 \mathrm{~nm}$ in mineral soil solution originated directly from the decomposition of a larger amount of root litter. However, sorption of DOC to mineral phase favors sorption of DOC with an aromatic structure (Kaiser and Guggenberger, 2000). Additionally, increased production of DOC from decomposition of root litter could over extended periods of time saturate the mineral phase, leading to less efficient sorption (Guggenberger and Kaiser, 2003) and manifest as increased DOC. Second, the increased root litter/exudates could act with a priming effect on SOM in the mineral B horizon. Root litter/rhizodeposition might be a relatively easily available $\mathrm{C}$ source that stimulated decomposition of old SOM found in the mineral soil (Kuzyakov, 2002), resulting in increased DOC. As SUVA (at both 254 and $280 \mathrm{~nm}$ ) in mineral B horizon leachates increased in the fertilized plots, sampled DOM likely contained more aromatic moieties (Dilling and Kaiser, 2002). These compounds are important for long-term sorptive preservation of OM in mineral soil (Kaiser and Guggenberger, 2000). Third, addition of mineral $\mathrm{N}$ to hardwood forests in Michigan, USA, induced suppression of the extracellular enzymes phenol oxidase and peroxidase with a concomitant increase in DOC and abundance of soluble phenolics (Waldrop and Zak, 2006). The elevated DOC concentrations in B horizon TLs leachates could have consequences for water quality as DOC is known to be a transporter of several metals and radionuclides (Tyler, 1981; Marley et al., 1993).

In O horizon, R-type lysimeter leachate DON was elevated in the N1 plots in 1995. In contrast, elevated DON in the Namended plots was observed in ZTL leachates only in 2009. McDowell et al. (1998) report increased soil water DON flux by a factor of two beneath the forest floor in a $\mathrm{N}$-amended Pine forest stand in Massachusetts, USA. DON in O horizon soil solution at Stråsan increased in response to $\mathrm{N}$ addition up to a factor of four (N1 plots in O horizon 2009). Both N1 plots at Stråsan displayed elevated DON concentrations (in excess of $6 \mathrm{mg} \mathrm{DON} \mathrm{L}^{-1}$ ) during early summer 2009; elevated DON concentrations in early summer were not apparent in 1995 (Fig. 1). The first sampling in 2009 took place 27 days after the application of ammonium nitrate. Seasonality of DON with high concentrations during early summer is reported for a coniferous forest (McDowell et al., 1998) and a grassland altitudinal gradient (Farrell et al., 2011). Stråsan represented a highly $\mathrm{N}$-limited ecosystem at the beginning of $\mathrm{N}$ treatments in 1967 (Tamm et al., 1974). The internal cycling of $\mathrm{N}$, determined as net-mineralization, at Stråsan increased by a factor of ten in N1 plots by 1996 (Andersson et al., 2001), and these conditions appeared to have been exacerbated in the $\mathrm{N} 1$ plots by 2010 with $\mathrm{NO}_{3}^{-}$as a major $\mathrm{N}$ species in $\mathrm{O}$ horizon leachates (Table 7). This indicates a move towards $\mathrm{N}$ saturation in the $\mathrm{N} 1$ plots. Although $\mathrm{N}$ addition was terminated in the N2 treatment by 1991 , DON was not elevated in 1995, but it was in 2009.

DON in mineral B horizon leachates was elevated in N2 plots in 1995 and in N1 plots in 2009. By 2009, DON in N2 plots in mineral soil leachates was still elevated but did not differ significantly from the control: thus DON in mineral soil leachates appeared to be driven by the continuous supply of mineral N. Both N2 (in 1995) and N1 (in 2009) approximately doubled DON in mineral B horizon. In a study by Pregitzer et al. (2004), DON leaching from mineral soil increased by a factor of six in response to eight years of $\mathrm{N}$ addition in a North American deciduous forest, although the sites in this study were possibly not $\mathrm{N}$ limited $(\mathrm{C} / \mathrm{N}$ in $\mathrm{O}_{e+a}$ ranging 17-21). Mineral soil DON in the N1 plots were elevated in the middle of summer 2009, approximately one month after DON concentrations peaked in the above-lying $\mathrm{O}$ horizon, suggesting that $\mathrm{O}$ horizon ZTL is indicative of DON fluxes from $\mathrm{O}$ horizon into the mineral soil.

The dynamics of $\mathrm{C} / \mathrm{N}$ stochiometry differed between solid and dissolved organic matter: the DOC/DON in O horizon was more responsive to long-term addition of mineral $\mathrm{N}$ and termination of $\mathrm{N}$ addition than $\mathrm{C} / \mathrm{N}$ of $\mathrm{O}$ horizon SOM (Fig. 2). Moreover, the annual mean DOC/DON-ratio in the $\mathrm{N}$ treatments showed contrasting temporal patterns in $\mathrm{O}$ horizon ZTL leachates. The decrease in DOC/DON of $\mathrm{N} 1$ plots between 1995 and 2009, as well as increased $\mathrm{NO}_{3}^{-}$, corroborates development towards $\mathrm{N}$ saturation. Although $\mathrm{O}$ horizon DON was elevated in the N2 treatment in 2009 compared to control, the DOC / DON of N2 approached control levels in 2009, indicating recovery from long-term $\mathrm{N}$ addition.

The results we present here also demonstrate that longterm $\mathrm{N}$ addition to a boreal forest sequestered $\mathrm{C}$ (only stemwood and $\mathrm{O}_{i+e+a}$ horizon $\mathrm{C}$ considered) at rates of $38.2 \pm 4.0\left(\mathrm{~N} 1\right.$ in 2010) and $32.3 \pm 1.1 \mathrm{~kg} \mathrm{Cha}^{-1} \mathrm{yr}^{-1}$ per added $\mathrm{kg} \mathrm{N} \mathrm{ha}^{-1} \mathrm{yr}^{-1}$ (N2 in 1997). These estimates, although conservative, are in the interval $20-40 \mathrm{~kg} \mathrm{Cha}^{-1} \mathrm{yr}^{-1}$ per $\mathrm{kg} \mathrm{Nha}^{-1} \mathrm{yr}^{-1}$ reported by de Vries et al. (2009) across non-N-saturated European forests. Increased soil $\mathrm{C}$ in $\mathrm{O}_{i+e+a}$ horizon contributed a little less than half of this sequestered $\mathrm{C}$, ranging 38-53\% over both $\mathrm{N}$ treatments and years. This was caused by increased production of litter and unchanged, or even decreased, per unit substrate, DOC. Moreover, respiration rates from $\mathrm{O}$ horizon material were suppressed in the N-treated plots at Stråsan in an incubation study (Sjöberg et al., 2003). The effect of long-term $\mathrm{N}$ addition on mineral soil $\mathrm{C}$ balance was unclear as the 
source of the increased DOC in $\mathrm{N}$-amended plots could not be fully determined. This is a matter in need of further research. The $\mathrm{N} 2$ treatment had elevated mineral B horizon DOC nineteen years after termination of $\mathrm{N}$ addition. This indicates that recovery from heavy $\mathrm{N}$ addition may be very slow even at sites originally strongly $\mathrm{N}$ limited: a finding with implications for the effect of $\mathrm{N}$ deposition on $\mathrm{C}$ balance of terrestrial ecosystems. Generally, mycorrhizal abundance decreases in response to $\mathrm{N}$ addition (Högberg et al., 2003; Treseder, 2004). Thus, changes to the soil microbial community composition and its function were likely in the N1 and $\mathrm{N} 2$ treatments. Detailed studies of the regulating function of soil biology on $\mathrm{C}$ and $\mathrm{N}$ cycling at Stråsan are needed to improve our understanding of these systems in the context of biogeochemical cycles and global change, e.g. terrestrial C balances and anthropogenic $\mathrm{N}$ deposition.

\section{Conclusions}

The effect of long-term addition of $\mathrm{N}$ on $\mathrm{O}$ horizon DOC concentration is a balance between direct and indirect effects. We present support for a positive influence of litterfall production on DOC in O horizon at Stråsan. There is no direct positive effect of long-term $\mathrm{N}$ addition on $\mathrm{O}$ horizon DOC: on the contrary, a negative effect per unit substrate $\mathrm{C}$ (soil $\mathrm{C}$ and litterfall production) is shown. This brings about an enhanced $\mathrm{C}$ sequestration in forest floor $\mathrm{O}$ horizon. Elevated $\mathrm{O}$ horizon DON and $\mathrm{NO}_{3}^{-}$in the ongoing $\mathrm{N}$ treatment, $\mathrm{N} 1$, indicates development towards $\mathrm{N}$ saturation. DON in O horizon leachate is elevated nineteen years after termination of $\mathrm{N}$ addition, although the DOC/DON approaches DOC/DON of control.

Long-term $\mathrm{N}$ addition approximately doubles leachate concentration of DOC and DON in mineral B horizon at Stråsan. This could have consequences for water quality as DOC is known to be a transporter of several metals and radionuclides. Nineteen years after termination of $\mathrm{N}$ addition, DON returns to control levels, but DOC remains elevated. These effects appear not to be driven by acidity but rather by biology. Increased DOC in both the ongoing and terminated $\mathrm{N}$ treatment are likely the result of decomposition of a larger amount of root litter, either directly producing DOC or indirectly via priming of old SOM, and/or a suppression of extracellular oxidative enzymes. Future work at Stråsan should aim to link changes to soil $\mathrm{C}$ and $\mathrm{N}$ cycling with detailed studies of soil biology, addressing processes in both $\mathrm{O}$ and mineral B horizon explicitly.
Acknowledgements. This work was supported by the FoMa Acidification Program of the Swedish University of Agricultural Sciences, SLU. The SLU Small Fund contributed to financial support. We gratefully acknowledge the contribution from Mikael Andersson, SLU, to the statistical analysis. Mona N. Högberg, SLU, assisted in acquisition of estimates of tree stand volumes in 2010. Three anonymous referees offered suggestions that improved the clarity and usefulness of this paper.

Edited by: J. W. Erisman

\section{References}

Andersson, P., Berggren, D., and Johnsson, L.: 30 Years of N Fertilisation in a Forest Ecosystem - The Fate of Added N and Effects on N Fluxes, Water Air Soil. Poll., 130, 637-642, 2001.

Andersson, P., Berggren, D., and Nilsson, I.: Indices for nitrogen status and nitrate leaching from Norway spruce (Picea abies (L.) Karst.) stands in Sweden, Forest Ecol. Manag., 157, 39-53, 2002.

Beier, C. and Hansen, K.: Evaluation of porous cup soil-water samplers under controlled field conditions: comparison of ceramic and PTFE cups, J. Soil Sci., 43, 261-271, 1992.

Berg, B. and Matzner, E.: Effect of $\mathrm{N}$ deposition on decomposition of plant litter and soil organic matter in forest systems, Environ. Rev., 5, 1-25, 1997.

Berggren Kleja, D., Andersson, P., Berdén, M., Johnsson, L., Nilsson, I., and Bergkvist, B.: Effekter av tillfört kväve på mobilisering, sammansättning och dynamik av löst organiskt material i en podsol [In Swedish], Effects of added nitrogen on mobilization, composition and dynamics of dissolved organic matter in a podzol, Report to the Swedish Environmental protection Agency, Department of Soil Sciences, Swedish University of Agricultural Sciences, Uppsala, 1998.

Boudot, J. P., Bel, H., Brahim, A., Steiman, R., and Seigle-Murandi, F.: Biodegradation of synthetic organo-metallic complexes of iron and aluminium with selected metal to carbon ratios, Soil Biol. Biochem., 21, 961-966, 1989.

Brandel, G.: Volume functions for individual trees, Scots pine (Pinus sylvestris), Norway spruce (Picea abies) and birch (Betula pendula \& Betula pubescens), Department of Forest Yield Research, Garpenberg, 72 pp., 1990.

Cairns, M. A., Brown, S., Helmer, E. H., and Baumgardner, G. A.: Root biomass allocation in the world's upland forests, Oecologia, 111, 1-11, 1997.

Callesen, I., Liski, J., Raulund-Rasmussen, K., Olsson, M. T., TauStrand, L., Vesterdal, L., and Westman, C. J.: Soil carbon stores in Nordic well-drained forest soils-relationships with climate and texture class, Glob. Change Biol., 9, 358-370, 2003.

Currie, W., Aber, J., McDowell, W., Boone, R., and Magill, A.: Vertical transport of dissolved organic $\mathrm{C}$ and $\mathrm{N}$ under long-term $\mathrm{N}$ amendments in pine and hardwood forests, Biogeochemistry, 35, 471-505, 1996.

de Vries, W., Solberg, S., Dobbertin, M., Sterba, H., Laubhann, D., van Oijen, M., Evans, C., Gundersen, P., Kros, J., Wamelink, G. W. W., Reinds, G. J., and Sutton, M. A.: The impact of nitrogen deposition on carbon sequestration by European forests and heathlands, Forest Ecol. Manag., 258, 1814-1823, 2009. 
Dilling, J. and Kaiser, K.: Estimation of the hydrophobic fraction of dissolved organic matter in water samples using UV photometry, Water Res., 36, 5037-5044, 2002.

Evans, C., Goodale, C., Caporn, S., Dise, N., Emmett, B., Fernandez, I., Field, C., Findlay, S., Lovett, G., Meesenburg, H., Moldan, F., and Sheppard, L.: Does elevated nitrogen deposition or ecosystem recovery from acidification drive increased dissolved organic carbon loss from upland soil? A review of evidence from field nitrogen addition experiments, Biogeochemistry, 91, 13-35, 2008.

Farrell, M., Hill, P. W., Farrar, J., Bardgett, R. D., and Jones, D. L.: Seasonal variation in soluble soil carbon and nitrogen across a grassland productivity gradient, Soil Biol. Biochem., 43, 835844, 2011.

Fog, K.: The effect of added nitrogen on the rate of decomposition of organic matter, Biol. Rev., 63, 433-462, 1988.

Fröberg, M., Kleja, D. B., Bergkvist, B., Tipping, E., and Mulder, J.: Dissolved Organic Carbon Leaching from a Coniferous Forest Floor: A Field Manipulation Experiment, Biogeochemistry, 75, 271-287, 2005.

Fröberg, M., Berggren, D., Bergkvist, B., Bryant, C., and Mulder, J.: Concentration and Fluxes of Dissolved Organic Carbon (DOC) in Three Norway Spruce Stands along a Climatic Gradient in Sweden, Biogeochemistry, 77, 1-23, 2006.

Galloway, J. N., Dentener, F. J., Capone, D. G., Boyer, E. W., Howarth, R. W., Seitzinger, S. P., Asner, G. P., Cleveland, C. C., Green, P. A., Holland, E. A., Karl, D. M., Michaels, A. F., Porter, J. H., Townsend, A. R., and Vöosmarty, C. J.: Nitrogen Cycles: Past, Present, and Future, Biogeochemistry, 70, 153-226, 2004.

Guggenberger, G.: Acidification effects on dissolved organic matter mobility in spruce forest ecosystems, Environ. Int., 20, 31-41, 1994.

Guggenberger, G. and Kaiser, K.: Dissolved organic matter in soil: challenging the paradigm of sorptive preservation, Geoderma, 113, 293-310, 2003.

Guggenberger, G., Zech, W., and Schulten, H.-R.: Formation and mobilization pathways of dissolved organic matter: evidence from chemical structural studies of organic matter fractions in acid forest floor solutions, Org. Geochem., 21, 51-66, 1994.

Gundersen, P., Emmett, B. A., Kjønaas, O. J., Koopmans, C. J., and Tietema, A.: Impact of nitrogen deposition on nitrogen cycling in forests: a synthesis of NITREX data, Forest Ecol. Manag., 101, 37-55, 1998.

Högberg, M. N., Erland, B., Nordgren, A., Arnebrant, K., and Högberg, P.: Contrasting Effects of Nitrogen Availability on Plant Carbon Supply to Mycorrhizal Fungi and Saprotrophs: A Hypothesis Based on Field Observations in Boreal Forest, New Phytol., 160, 225-238, 2003.

Kaiser, K. and Guggenberger, G.: The role of DOM sorption to mineral surfaces in the preservation of organic matter in soils, Org. Geochem., 31, 711-725, 2000.

Kalbitz, K., Solinger, S., Park, J.-H., Michalzik, B., and Matzner, E.: Controls on the Dynamics of Dissolved Organic Matter in Soils: A Review, Soil Sci., 165, 277-304, 2000.

Kalbitz, K., Meyer, A., Yang, R., and Gerstberger, P.: Response of dissolved organic matter in the forest floor to long-term manipulation of litter and throughfall inputs, Biogeochemistry, 86, 301$318,2007$.
Kleja, D., Svensson, M., Majdi, H., Jansson, P.-E., Langvall, O., Bergkvist, B., Johansson, M.-B., Weslien, P., Truusb, L., Lindroth, A., and Ågren, G.: Pools and fluxes of carbon in three Norway spruce ecosystems along a climatic gradient in Sweden, Biogeochemistry, 89, 7-25, 2008.

Knorr, M., Frey, S. D., and Curtis, P. S.: Nitrogen Additions and Litter Decomposition: A Meta-Analysis, Ecology, 86, 3252-3257, 2005.

Kuzyakov, Y.: Review: Factors affecting rhizosphere priming effects, J. Plant Nutr. Soil Sci., 165, 382-396, 2002.

Leenheer, J. A.: Comprehensive approach to preparative isolation and fractionation of dissolved organic carbon from natural waters and wastewaters, Environ. Sci. Technol., 15, 578-587, 1981.

Marley, N. A., Gaffney, J. S., Oriandini, K. A., and Cunningham, M. M.: Evidence for radionuclide transport and mobilization in a shallow, sandy aquifer, Environ. Sci. Technol., 27, 2456-2461, 1993.

McDowell, W. H., Currie, W. S., Aber, J. D., and Yano, Y.: Effects of chronic nitrogen amendments on production of dissolved organic carbon and nitrogen in forest soils, Water Air Soil. Poll., 105, 175-182, 1998.

Park, J.-H., Kalbitz, K., and Matzner, E.: Resource control on the production of dissolved organic carbon and nitrogen in a deciduous forest floor, Soil Biol. Biochem., 34, 813-822, 2002.

Pihl Karlsson, G., Akselsson, C., Hellsten, S., and Karlsson, P. E.: Reduced European emissions of S and N - Effects on air concentrations, deposition and soil water chemistry in Swedish forests, Environ. Pollut., 159, 3571-3582, 2011.

Pregitzer, K., Zak, D., Burton, A., Ashby, J., and MacDonald, N.: Chronic nitrate additions dramatically increase the export of carbon and nitrogen from northern hardwood ecosystems, Biogeochemistry, 68, 179-197, 2004.

Raastad, I. A. and Mulder, J.: Dissoved organic matter (DOM) in acid forest soils at Gårdsjön (Sweden): natural variabilities and effects of increased input of nitrogen and of reversal of acidification, Water Air Soil Poll., 114, 199-219, 1999.

Saarsalmi, A., Starr, M., Hokkanen, T., Ukonmaanaho, L., Kukkola, M., Nöjd, P., and Sievänen, R.: Predicting annual canopy litterfall production for Norway spruce (Picea abies (L.) Karst.) stands, Forest Ecol. Manag., 242, 578-586, 2007.

Schlesinger, W. H.: Carbon Balance in Terrestrial Detritus, Annu. Rev. Ecol. Syst., 8, 51-81, 1977.

Schmidt, B. H. M., Wang, C.-P., Chang, S.-C., and Matzner, E.: High precipitation causes large fluxes of dissolved organic carbon and nitrogen in a subtropical montane Chamaecyparis forest in Taiwan, Biogeochemistry, 101, 243-256, 2010.

Sinsabaugh, R. L., Zak, D. R., Gallo, M., Lauber, C., and Amonette, R.: Nitrogen deposition and dissolved organic carbon production in northern temperate forests, Soil Biol. Biochem., 36, 1509-1515, 2004.

Sjöberg, G., Bergkvist, B., Berggren, D., and Nilsson, S. I.: Longterm $\mathrm{N}$ addition effects on the $\mathrm{C}$ mineralization and DOC production in mor humus under spruce, Soil Biol. Biochem., 35, 1305-1315, 2003.

Tamm, C.-O., Aronsson, A., and Burgtorf, H.: The optimum nutrition experiment Stråsan, A brief description of an experiment in a young stand of Norway spruce (Picea abies Karst.), Department of Forest Ecology and Forest Soils, Stockholm, 1974. 
Treseder, K. K.: A Meta-Analysis of Mycorrhizal Responses to Nitrogen, Phosphorus, and Atmospheric $\mathrm{CO}_{2}$ in Field Studies, New Phytol., 164, 347-355, 2004.

Tyler, G.: Leaching of metals from the A-horizon of a spruce forest soil, Water Air Soil. Poll., 15, 353-369, 1981.

Viro, P. J.: On the determination of stoniness, Comminucationes Instituti Forestalis Fenniae, 40, 1-19, 1952.
Waldrop, M. and Zak, D.: Response of oxidative enzyme activities to nitrogen deposition affects soil concentrations of dissolved organic carbon, Ecosystems, 9, 921-933, 2006.

Zech, W. and Guggenberger, G.: Organic matter dynamics in forest soils of temperate and tropical ecosystems, in: Humic substances in Terrestrial Ecosystems, edited by: Piccolo, A., Elsevier, Amsterdam, The Netherlands, 101-170, 1996. 